\title{
"Rappers React to Covid-19": What the Mobilisation of Chinese Rappers Teaches Us about Artistic Engagement in Times of Crisis
}

\section{Grégoire Bienvenu}

Translator. Elizabeth Guill

\section{(2) OpenEdition}

\section{Journals}

Electronic version

URL: https://journals.openedition.org/chinaperspectives/11455

DOI: 10.4000/chinaperspectives. 11455

ISSN: 1996-4617

Publisher

Centre d'étude français sur la Chine contemporaine

\section{Printed version}

Date of publication: 1 March 2021

Number of pages: $49-53$

ISSN: 2070-3449

\section{Electronic reference}

Grégoire Bienvenu, "“'Rappers React to Covid-19": What the Mobilisation of Chinese Rappers Teaches Us about Artistic Engagement in Times of Crisis", China Perspectives [Online], 2021/1 | 2021, Online since 01 March 2021, connection on 01 April 2022. URL: http://journals.openedition.org/ chinaperspectives/11455 ; DOI: https://doi.org/10.4000/chinaperspectives.11455 


\section{"Rappers React to Covid-19":}

\section{What the Mobilisation of Chinese}

\section{Rappers Teaches Us about Artistic}

Engagement in Times of Crisis

GRÉCOIRE BIENVENU

KEYWORDS: Covid-19, hip-hop, rap, China, charity songs.

"It's for the soldiers fighting in the hospitals all night

Thanks for the lanterns lighting up the dark"

-AR ft. Q.luv ${ }^{1}$

$\mathrm{T}$ he "ad hoc coming together of popular musicians to record discs and/ or perform on stage with the aim of raising funds for philanthropic purposes is known as charity rock." Charity songs rely on the media system and the recording industry to transmit a "collective conscience likely to induce change" (Carlet and Seca 2005). The mobilisation of artists in times of humanitarian crisis is far from new. George Harrison (1971) and Bob Celdof $(1984,1986)$ were the first celebrities to use their fame and artistic network to support populations in danger. In China, the first recording of a charity song (gongyi gequ 公益歌曲) dates back to 1986, when a hundred young singers dressed in yellow and pink jackets sang "Let the World be Full of Love" (rang shijie chongman ai 讓世界充滿愛) in the Beijing Workers' Stadium to celebrate the International Year of Peace. More recently, new charity songs have emerged following certain catastrophes: "Hand in hand" (shouqianshou 手率手) in Taiwan and "Walk All the Way" (yilu tongxing 一路同行) during the SARS epidemic (2003); and "Wings in the Wind" (feng zhongdi yuyi 風中的羽翼), “The Same Dream" (tongyige mengxiang 同個夢想), and "Promise" (chengnuo 承諾) after the Wenchuan earthquake (Sichuan, 2008). During the first weeks of the Covid-19 epidemic that became a pandemic, a not inconsiderable number of charity songs were recorded by Chinese musicians, with technological developments facilitating online artistic collaborations whilst at the same time helping them reach a wider audience thanks to streaming platforms. On the initiative of iQiyi, "Let the World be Full of Love" was revived and recorded by international singers and a hundred Chinese artists under the direction of Guo Feng. The music streaming platforms also opened sections to songs dedicated to Wuhan and the pandemic (shengyuan wuhan 聲援武漢), where amateur artists rubbed shoulders with professionals. ${ }^{3}$

Chinese rappers were amongst the first artists to act in the days following the quarantining of the country, providing observers with an illustration of the social and political role hip-hop has acquired in just a few years. From an underground practice adopted by marginalised young people, rap has become music for a wide audience in China, notably thanks to the success of the programme The Rap of China (Zhongguo you xiha 中國有嘻哈), broadcasted in 2017 on iQiyi. As a result of their increased visibility on Chinese social media, certain rappers have become very well-known (Flew, Ryan, and Su 2019), to the extent that the doors of CCTV's 2020 New Year's Gala were opened to this type of music. ${ }^{4}$ This whirlwind success amongst young people in China has nonetheless been carefully controlled by the authorities, who censure aspects considered unsuited to the political context, whilst favouring artists who embrace the national narrative (Amar 2018). The digitalisation of music consumption as well as shortcomings in the system of protection of royalties in China ${ }^{5}$ has contributed to the tightening of controls on the Chinese music industry and on the content of the work published, allowing the authorities to decide which songs to make available to Chinese listeners. In this respect, several academics have therefore been able to demonstrate the relationships (voluntary or otherwise) between Chinese hip-hop and the central government (Zou 2019; Gu and Zhou 2019) whilst voices have been raised abroad criticising its representatives' lack of political engagement. ${ }^{6}$

1. “夢想” (mengxiang), 27 January 2020. See the list of songs at the end of the article for the original titles.

2. iQiyi 愛奇藝 is a Chinese video streaming platform similar to Netflix.

3. Xu Yuyang, “從SARS到今天: 公益歌曲在疫情時期的治愈之力” (Cong SARS dao jintian: Congyi gequ zai yiqing shiqi de zhiyu zhi li, From SARS to today:The healing power of charity songs during the epidemic), 新浪網 Sina, 3 March 2020, https://k.sina.cn/article_1496814565_593793e50270 Opvdf.html?from=ent\&subch=oent (accessed on 10 October 2020).

4. Allison Jiang, "China's Traditional Spring Festival TV Gala Chases Younger Viewers with 'Rap of China' Crossover," RADII, 16 January 2020, https://radiichina.com/lay-zhang-wild-wolf-discospring-festival-gala/ (accessed on 20 January 2020).

5. Fan Shuhong, "'We Need a Generational Effort': Music Lawyer Eric Zhao Crusades Against Piracy," RADII, 17 October 2019, https://radiichina.com/music-lawyer-eric-zhao/ (accessed on 18 December 2019).

6. Yi-Ling Liu, "Why Chinese rappers don't fight the power," BBC, 6 November 2019, http://www. bbc.com/culture/story/20191106-why-chinese-rappers-dont-fight-the-power (accessed on 12 December 2019). 
In the present circumstances, it is interesting to examine the way in which Chinese rappers used their art during the first month of the Covid-19 pandemic by developing a non-official - but not necessarily subversive discourse on the health crisis. Between 23 January and 26 February 2020, 21 songs on this theme were put on the Internet, and a considerable number of rappers expressed themselves via posts on the Sina Weibo microblogging site and on Instagram. Although this form of action differs from the classic charity rock model, it nonetheless enables us to analyse a public and artistic expression of opinion in the midst of a health crisis as well as the fresh political tensions it has brought to the surface in China. ${ }^{7}$ Acting on the principle that catastrophes influence the production of music on occasion but that music also nourishes the narrative that is constructed from the events, ${ }^{8}$ might it not therefore be appropriate to examine the significance of music production in China in a time of crisis?

\section{From charity song to Chinese-style useful work}

The major artistic and humanitarian actions of the twentieth century have been severely criticised in the past for their construction of a quasimythological scenography in which "big-hearted" celebrities spontaneously and disinterestedly engage with the victims of disasters (Carlet and Seca 2005). Above all, as with humanitarian songs, Chinese artists who take action usually do "useful work" by amassing important symbolic capital that will later serve their careers (Velasco-Pufleau 2013). At the beginning of the pandemic, in January 2020, Chinese rappers found themselves from one day to the next with no stage to perform on following the closure of clubs and concert halls as well as the cancellation of the spring festivals. In all, almost 20,000 shows were cancelled or postponed in three months, engendering losses estimated at two billion RMB for the Chinese music industry. ${ }^{9}$ Although this period might seem to favour creativity, since artists have more time, it above all means that musicians are deprived of revenue, since live performances represent their main source of income along with advertising contracts (Flew, Ryan and Su 2019). This economic model, under direct threat from the health crisis, exercises a real force of normalisation on music production and may partly explain the extent of the artistic mobilisation we have seen.

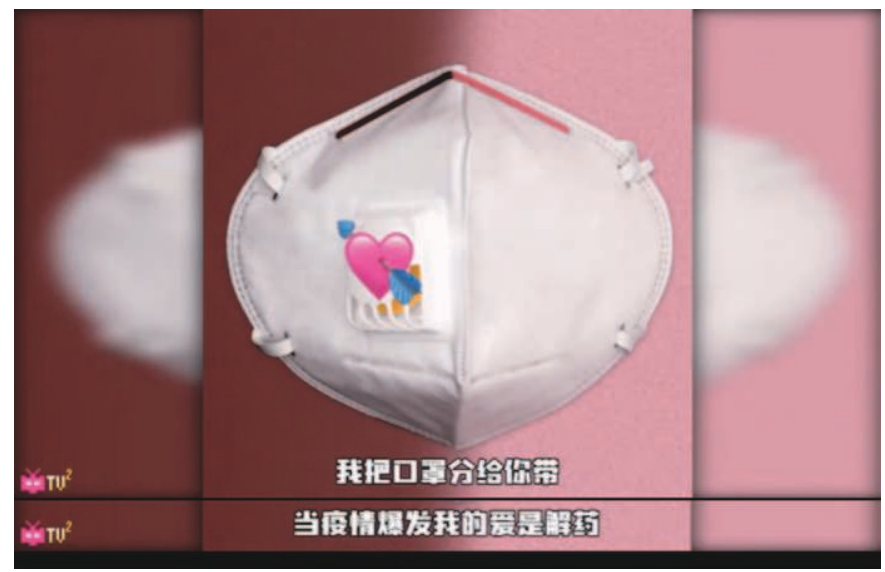

Illustration 1. Extract from the song, "Mask" ( $\square$ 罩 - Masiwei, KnowKnow). "I give you my mask, when the epidemic breaks out, my love is the antidote." Credit: screenshot by the author.

The rise of music produced at home and the impossibility of performing on stage have, for example, incited certain Chinese rappers to record songs on the pandemic for purely commercial ends. This is the case with Masiwei 馬
思唯 and KnowKnow, where the title and sleeve of the song "Mask" lead one to imagine a link with Covid-19 whilst in fact it is a love story with simple, universal lyrics. Issued a few days before the release of Masiwei's first solo album, the song reveals an underlying market strategy that has provoked a great deal of criticism from listeners. ${ }^{10}$ The Sichuanese singers Vava and Wang Yitai 王以太 also recorded a song whose promotional strategy, heavily reinforced by teasing from a recording studio in Los Angeles, ${ }^{11}$ reveals an objective that is more commercial than humanitarian. The formalism and professionalism that surrounded the promotional campaign for "Life is Beautiful" also tend to call into question the spontaneity and disinterested nature of their initiative.

In attaining a form of popular success, rap in China has been transformed under the effect of a commodification favoured by the involvement of major brands and advertisers. However, the main key to success for a pop artist in China remains the compatibility of their work with the national ideology (Fung 2008). In 2017, the popular success of the first season of the programme The Rap of China, which amassed almost three billion online views, ${ }^{12}$ led the General Administration of Press, Publication, Radio, Film and Television (SAPPRFT - now the NRTA, National Radio and Television Administration) to temporarily bar representatives of hip-hop culture from access to the national media (Amar 2018). The return of the programme the following year was subject to strict observance of the concept of "positive energy" (zheng nengliang 正能量), a term used by official propaganda to restrict public debate to a non-adversarial ideology that prevents the construction of counter-discourse (Chen and Wang 2020). The development of Chinese rap therefore falls in line with Xi Jinping's pronouncement on the arts in 2014: obscenity (esu 惡俗) and vulgarity (disu 低俗), singled out in a communication issued by the SAPPRFT, ${ }^{13}$ have disappeared from consumer formats. During the health crisis, this control of creativity can be seen in the songs produced by rappers. The titles of the songs published in the two first weeks that followed the quarantining of Wuhan reflect real optimism in the face of disaster: "Tomorrow All Will be Well," "Hope," "Roll on Spring, Can't Wait to See You." In these songs, the artists use the vocabulary

7. On social media, where Chinese web users expressed their anger at the death of Dr. Li Wenliang, as well as in open letters published by intellectuals opposed to the regime. See Gerry Shih, "Doctor's death from coronavirus sparks a digital uprising, rattling China's leaders," The Washington Post, 7 February 2020, https://www.washingtonpost.com/world/asia_pacific/ doctors-death-from-coronavirus-sparks-adigital-uprising-rattling-chinas-leaders/2020/02/07/ a4cb3492-4998-11ea-8a1f-de1597be6cbc_story.html (accessed on 20 February 2020); Xu Zhiyong, "Dear Chairman Xi, It's Time for You to Go" (translation by Gérémie R. Barmé), China File, 26 February 2020, https://www.chinafile.com/reporting-opinion/viewpoint/dear-chairmanxi-its-time-you-go (accessed on 10 March 2020).

8. "Songs about disasters," The Kennedy Center, https://www.kennedy-center.org/education/ resources-for-educators/classroom-resources/media-and-interactives/media/music/songsabout/songs-about-disasters/ (accessed on 29 October 2020).

9. About 260 million euros. Benson Zhang, Dave Brooks, "Coronavirus paralyzes China's live sector as concert cancellations and box-office losses mount," Billboard, 14 February 2020, https://www. billboard.com/articles/news/international/8551043/coronavirus-paralyzes-china-live-musicsector-concerts (accessed on 28 February 2020)

10. “畸形兒被馬思唯 KnowKnow 新歌“口罩,難聽哭了?" (Jixinger bei Masiwei KnowKnow xinge "kouzhao" nanting kule, Astonishing new song by Masiwei and Knowknow "Mask", so inaudible it makes you want to cry?), 説唱 HIPHOP (WeChat), 20 February 2020, https://mp.weixin.q9.com/ s/qNjz3QxhdPiURFo9vkvNtg (accessed on 20 February 2020).

11. "VaVa 毛衍七, 王以太, Doka2, Jessi, 'Life is beautiful'," presentation video released by Warner Music China on 23 February 2020, https://www.youtube.com/watch?v=w4jBKhQWq20\&t=12s (accessed on 25 February 2020).

12. Kenrick Davis, "'The Rap of China' returns after off-beat year," Sixth Tone, 13 June 2018, http:// www.sixthtone.com/news/1002614/the-rap-of-china-returns-after-off-beat-year (accessed on 11 July 2018).

13. Casey Quackenbush and Aria Chen, "Tasteless, vulgar and obscene. China just banned hip-hop culture and tattoos from television," Time, 22 January 2018, https://time.com/5112061/chinahip-hop-ban-tattoos-television/ (accessed on 26 January 2018). 
of improvement to create a positive message underlined by melodious instrumentation. Through their words, the rappers send their support to the Chinese people and call for solidarity and vigilance, reinforcing the national narrative shaped by the crisis.

\section{The doctor: A depoliticised and consensual figure}

Like the government and national media during the crisis, many rappers have used the figure of the doctor in their songs, sometimes presented as a national hero, sometimes likened to a soldier going into battle. The Guangdong rapper JR FOG was the first to dedicate a song to them, entitled, Heroes. In the lyrics we find several metonymies commonly used to describe doctors in Chinese propaganda, "white coats" (baise dagua 白色大袿), "heroes in white coats" (baise yifu de yingxiong 白色衣服的英雄), and "white angels" (baise de tianshi 白色的天使).

\section{等你凱旋 \\ Waiting for your triumph \\ 白色衣服的英雄 義無反顧對抗疫情我心痛 \\ Heroes in white clothes, look back to fight the epidemic}

\section{他們鬆開了摰愛的手擋在了最前方的危險中}

They let go the hands of their beloved ones,

get in the way to face the danger

\section{沒有什麼能沖散一心的萬衆一切在掌控}

Nothing can break the heart of the people, everything is under control

\section{加油武漢加油中國加油英雄}

Come on Wuhan, come on China, come on heroes

寶石 GEM, the first rapper to have taken part in CCTV's New Year gala, also issued a song dedicated to the doctors: "Coing to War" (chuzheng 出 征). He links his words to the warrior universe of General Yue Fei 岳飛, taking up the verses of one of his poems: 滿江紅 (manjianghong). In his text, the rapper likens the figure of the doctor to that of the fighter and soldier and casts the virus as an enemy (敵愾 dikai) to be eliminated (滅掉 miediao). But over and above the words, the illustrations used by these two rappers also reveal the proximity of the official discourse and that of music composition at the start of the health crisis. The sleeves that accompany the songs use the same illustration of a doctor seen from the back, wearing a white coat and attaching a mask to his face. The video clips, in their role of "political images" (Gow 1994), use the same illustrations as the national media. Pictures of hospital staff hard at work, patients being taken in charge, crying families, and the soldiers of the People's Liberation Army on a war footing succeed each other. Despite their white coats and faces marked by effort, the doctors are re-humanised with the help of sequences that show them united, hugging each other, or writing their names on their coats. We also see Dr. Zhong Nanshan 鐘南山, "SARS heroes,"14 the construction of Wuhan Hospital in less than ten days, as well as Chinese factories massproducing masks and medicines. The staging and rhythm show a China that is mobilised, organised, and determined to combat the virus, visual elements of a rhetoric that has enabled the nationalist propaganda that followed to affirm the "superiority of the Chinese model" and its "victory in the People's war" being fought against Covid-19. ${ }^{15}$

The figure of the doctor, and more broadly, the world of the hospital, gives

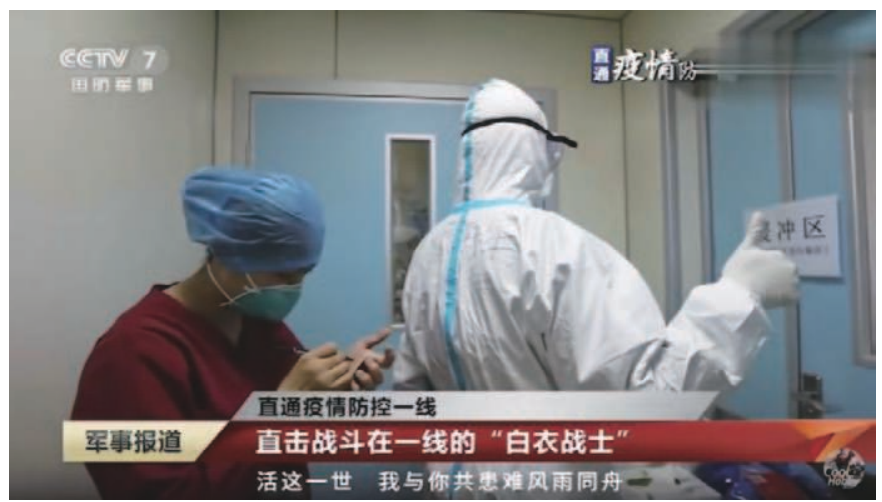

Illustration 2. Extract from the clip "Going to War" (出征 - 寶石 GEM). In this image from CCTV, a nurse writes the name of a doctor, hidden under several layers of protective clothing, on his coat, thereby rehumanising him.

Credit: screenshot by the author.

Chinese rappers a depoliticised and consensual environment that allows them to construct a narrative of the health crisis that does not contradict the official narrative. The use of figures of speech and general, imprecise terms also allows them not to take a stand at a time in the crisis when the authorities are dissociating the good doctor (Xu Hui 徐輝) ${ }^{16}$ from the bad (Li Wenliang 李文亮). The choice of images therefore reveals a partisan policy, since the 寶石 GEM and JR FOG clips offer a certain picture of the crisis, preferable to other more critical images such as those of the citizen journalists Fang Bin 方斌 and Chen Qiushi 陳秋實. ${ }^{17}$

\section{Implied criticism}

In the first weeks of the pandemic, the death of Li Wenliang, ${ }^{18}$ problems with the distribution of resources by humanitarian associations, ${ }^{19}$ and $X i$ Jinping's handling of the crisis $^{20}$ gave grounds for fresh criticism of the authorities by the Chinese people and led to a great wave of online protest. ${ }^{21}$ As for music, whilst the 13 songs published in the two weeks following the quarantining of Wuhan chose positive subjects (solidarity, hope) and catchy instrumentals, the next batch of songs adopted a different tone. The vocabulary used in the texts changed, and certain rappers now openly expressed their pessimism, as in "Degenerate DEMO," "Blind" (Xiazi

14. Yang Sheng, "Zhong's tears for Dr. Li Wenliang not to be twisted," Global Times, 12 February 2020, https://www.globaltimes.cn/content/1179381.shtml (accessed on 2 March 2020).

15. Filip Sebok, "Inside of China's Global Propaganda Campaign on COVID-19," China Observers, 16 March 2020, https://chinaobservers.eu/inside-of-chinas-global-propaganda-campaign-oncovid-19/ (accessed on 11 July 2020).

16. Yang Sheng, "Zhong's tears for Dr. Li Wenliang not to be twisted," Global Times, 12 February 2020, https://www.globaltimes.cn/content/1179381.shtml (accessed on 2 March 2020).

17. "Coronavirus: Why have two reporters in Wuhan disappeared?," BBC, 14 February 2020, https:// www.bbc.com/news/world-asia-china-51486106 (accessed on 20 March 2020).

18. Gerry Shih, "Doctor's death from coronavirus sparks a digital uprising, rattling China's leaders," The Washington Post, 7 February 2020, https://www.washingtonpost.com/world/asia_pacific/ doctors-death-from-coronavirus-sparks-a-digital-uprising-rattling-chinas-leaders/2020/02/07/ a4cb3492-4998-11ea-8a1f-de1597be6cbc_story.html (accessed on 26 May 2020).

19. Julia Hollingsworth and Natalie Thomas, "China's Red Cross is under fire for not getting supplies to hospitals fighting coronavirus. That's a problem for the government," CNN, 6 February 2020, https://www.cnn.com/2020/02/06/asia/red-cross-china-donations-intl-hnk/index.html (accessed on 4 March 2020)

20. Xu Zhiyong, "Dear Chairman Xi, It's Time for You to Go" (translation by Gérémie R. Barmé), China File, 26 February 2020, https://www.chinafile.com/reporting-opinion/viewpoint/dear-chairmanxi-its-time-you-go (accessed on 10 March 2020).

21. Vivian Wang, Javier C. Hernandez, "Coronavirus crisis awakens a sleeping giant: China's youth," The New York Times, 28 March 2020, https:/www.nytimes.com/2020/03/28/world/asia/ coronavirus-china-youth.html (accessed on 11 July 2020). 
瞎子), and "Nightmare" (Emeng 哥夢). Several songs were even banned or censored on their release. ${ }^{22}$ The more frequent use of opaque language can also be seen (Arsène 2011), allowing rappers to continue to transmit their message within the context of increasing restrictions. According to Séverine Arsène, Chinese Internet platforms represent a space offering a certain degree of anonymity where censure from "above" does not prevent other forms of committed discourse from being expressed "from below." In China, the use of a double language that aims to circumvent the authorities is not, moreover, the preserve of the hip-hop community. Artists and internet users also use their ingenuity to play on the different possibilities of the Chinese language to comment on delicate subjects. ${ }^{23}$ Like the writer jia Pingwa before them (Chen 2015), several rappers conceal with the help of "**" words that would have probably resulted in their exclusion from streaming platforms. "Disaster" (zainan 災難), "death" (siwang 死亡), and "bereavement" (daonian 悼念) do not appear in the words of the songs such as they are re-transcribed on the music platforms, without disappearing from the audio track however. Other words such as "Wuhan" and "virus" (bingdu 病毒) are reduced to their initials (WH and BD) although these same terms appear in full in the words of a song released earlier by Pissy 小李, member of the nationalist rap group $\mathrm{CD} \mathrm{Rev}{ }_{1}^{24}$ revealing two-tier censorship depending on the date of publication and the message transmitted in the songs.

\section{Should I Say I Love You

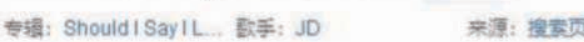

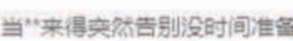

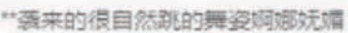

Illustration 3. Words of "Should I Say I Love You" (JD) presented on the music streaming platform 網易 雲 (NetEase).

Credit: screenshot by the author

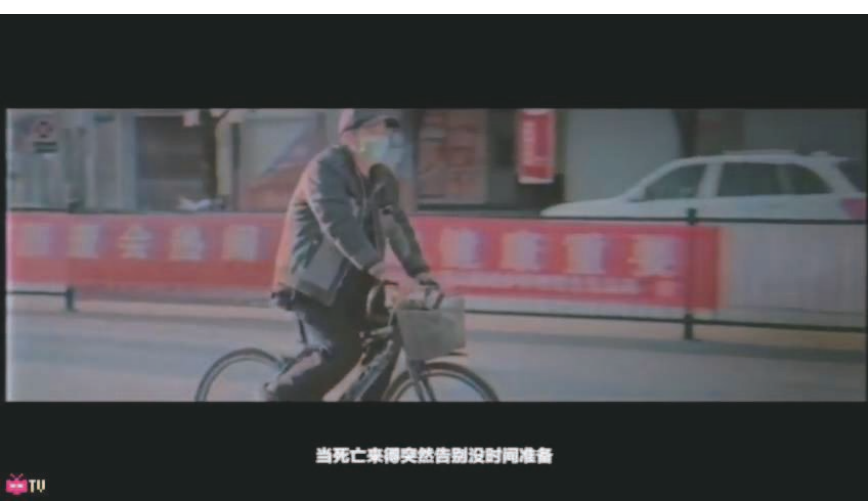

Illustration 4. Words of "Should I Say I Love You" (JD) presented on YouTube.

"When death comes suddenly, there is no time to get ready to go,

The attack by the virus is so natural, its dance so full of grace and charm."

Credit: screenshot by the author

On 12 February 2020, whilst the country was at a standstill and the handling of the crisis continued to be the subject of discussion on the Internet, MC Guangguang 光光, one of the veterans of Chinese hip-hop and from Nanking, published the song "Blind" (Xiazi 瞎子). Whilst never referring to the health crisis and therefore circumventing censorship, the rapper made one of the most explicit criticisms of the handling of information and the health disaster. ${ }^{25}$

\section{請你別説了別説了}

Please stop talking, stop talking

\section{我像個瞎子只能够看到你想讓我看到的}

I'm like a blind man who can only see what you want me to see

\section{那些編造的顛倒的你是怎麼辦到的}

How could you have made those fabricated and distorted words?

Known for his straight talking, MC Guangguang refers in his text to the whistleblowers as "buzzing mosquitoes" (wenzi duole wengwengweng 蚊子多了嗡嗡嗡) that are silenced. ${ }^{26}$ He questions the transparency of information controlled by those who "claim to want our good but are cultivating vermin behind the scenes" (yangzhe zhuchong haizai jiazhuang tianmi 養著蛙蟲還在假裝甜蜜) and multiplies the number of hidden transcriptions (Arsène 2011), implicitly describing a political power with an "ugly face" (zuilian zhefu hen 嘴臉這副狠) that is attempting to "once again change its own past" (chongxin qu xiugai ziji de jiyi 重新去修改自己的記 憶). The stance taken in the words of MC Guangguang reveals an opaque forum of expression reinforcing the idea that Chinese artists are not passive agents regulated by the censors, but regularly push back the limits of what is accepted in order to expand their audience (Fung 2008). The abundance of metaphors and double meanings in MC Guangguang's text may legitimately cast doubt on his message but, considering the circumstances under which the song was released, it would seem totally improbable that his audience did not possess the keys that would enable them to decode and understand its words.

\section{Conclusion}

In the face of an unprecedented health crisis, the Chinese rap scene showed itself to be reactive and mobilised by recording and releasing a considerable number of songs in record time, whilst at the same time moving away from the charity song model that had prevailed until then. Artistic expression on the pandemic participated at first in the general messaging on the crisis $^{27}$ by praising health care staff and expressing the support of rappers for the inhabitants of Wuhan. However, the development of Covid-19 and the management of events in China have changed the nature of mobilisation amongst musicians. The body of songs listed suggests a critical turning point adopted by certain rappers that make use of a realistic vocabulary and use indirect writing to avoid censure by the Chinese authorities. Although singing in a time of crisis would previously have seemed to be a cathartic exercise

22. Fan Shuhong, "Chinese Rap Wrap: Higher Brothers' Masiwei Drops Loved Up Solo Album," RADII, 5 March 2020, https://radiichina.com/chinese-rap-masiwei-prince-charming/ (accessed on 5 January 2021).

23. "Pho noodles and pandas: How China's social media users created a new language to beat government censorship on COVID-19," Amnesty International, 2020, https://www.amnesty.org/ en/latest/news/2020/03/china-social-media-language-government-censorship-covid/ (accessed on 29 October 2020)

24. Fan Shuhong, Meet CD REV: "China's 'reddest' rap crew," RADII, 6 December 2017, https:// radiichina.com/meet-cd-rev-chinas-reddest-rap-crew/ (consulted on 18 December 2018).

25. Fan Shuhong, "Chinese Rap Wrap: Rising Star Lexie Liu Stuns Mainstream TV," RADII, 19 February 2020, https://radiichina.com/lexie-liu-singer-chinese-rap/ (accessed on 22 February 2020).

26. “光光新歌我像個瞎子只能够看到你想讓我看到的” (Guangguang xinge : wo xiang ge xiazi zhineng gou kandao ni xiang rang wo kandao de, New song by Guangguang: I am like a blind man who can only see what you let me see), Xiaogiang Shushu, Xiha China, February 2020, https://www.xihachina.com/42928.html (accessed on 30 October 2020).

27. The song by 小李 Pissy “明天會好的” was shared on the Weibo account of People's Daily (人 民日報) on 29 January 2020, https://www.weibo.com/2803301701/IrKlk2RRt?type=comment (accessed on 5 March 2020). 
in which celebrities expressed their commitment in large ecumenical gatherings, the abundance of Chinese rap songs at the beginning of the Covid-19 pandemic reveals a change of approach in the artists' humanitarian engagement that does not, for all that, escape the critics. Finally, it is perhaps the reaction of an internet user on Douban ${ }^{28}$ that best illustrates the sentiment shared by many observers of Chinese hip-hop at the beginning of the pandemic:

唱歌要是有用的話 韓紅不比你會唱 她什麼不去唱歌去運物資? If singing were useful, Han $\mathrm{Hong}^{29}$ would sing better than you. But she does not sing, she acts by transporting supplies.
I Translated by Elizabeth Guill.

I Grégoire Bienvenu is a doctoral student at the IRMECCEN of the Sorbonne Nouvelle - Paris 3, and at the ICS of the University of Communication of China (中國傳媒大學). Centre Censier, 13 rue de Santeuil, 75231 Paris Cedex 05, France (gregoire.bienvenu@sorbonne-nouvelle.fr).

28. See: https://www.douban.com/group/topic/164837930/ (accessed on 20 February 2020).

29. Han Hong is a famous Chinese singer who in 2012 founded the "Han Hong Love Charity Foundation" (Han Hong aixin cishan jijinhui 韓紅愛心慈善基金會) to bring help to people affected by natural disasters. On 24 January 2020, the foundation launched the programme "Han Hong Love to the Rescue of Wuhan" (Han Hong aixin chiyuan Wuhan 韓紅愛心馳援武 漢) and collected more than 140 million RMB to buy medical equipment for the Hubei region. See Gabriel Corsetti, "The Han Hong Foundation: How a Celebrity Stepped Up Against Covid-19," China Development Brief, 10 July 2020, https://chinadevelopmentbrief.cn/reports/the-han-hongfoundation-how-a-celebrity-stepped-up-against-covid-19/ (accessed on 21 December 2020).

\section{List of songs studied in this article (in chronological order)}

25 January 2020. 幼稚園殺手 Youzhiyuan shashou, Kindergarten Killer. "守護” (Shouhu, To Protect).

25 January 2020. 惡童 Etong, ETON. "共渡” (Gongdu, Spending Time Together).

27 January 2020. Pissy, 小李 Xiaoli." 明天會好的” (Mingtian hui hao de, Tomorrow Will Be Ok).

27 January 2020. AR, Q.luv. "希望” (Xiwang, Hope).

2 February 2020. NOUS. "Untitled."

3 February 2020. LASTKINGLX, 劉炫廷 Liuxuanting. "Mask OFF, Remix."

4 February 2020. Muti, 李棒棒 Li Bangbang. “期待春天期待你” (Qidai chuntian qidai ni, Cant' Wait for the Spring, Can't Wait for You).

5 February 2020. 孫旭 Sun Xu. “健康宅” (Jiankang zhai, Healthy House).

5 February 2020. JR FOG. "Heroes."

8 February 2020. 寶石 GEM, Baoshi GEM. “出征” (Chuzheng, Going to War).
8 February 2020. Damnshine, 汪涵 Wanghan, 馬可 Make, \$CC731. “屋 檐” (Wuyan, Eave).

9 February 2020. KIT, 翌yi. “空城” (Kongcheng, Empty City).

9 February 2020. KEY.L, 劉聰 Liucong. "Hello 2020."

11 February 2020. Vava, 王以太 Wang Yitai, Dok2, Jessi. "Life is Beautiful."

11 February 2020. Killa4nia, 魚頭 Yutou. "冒險島” (Maoxian dao, Adventure Island).

13 February 2020. Ranzer. "Degenerate DEMO".

13 February 2020. MC 光光 (MC Guangguang). "瞎子” (Xiazi, Blind).

19 February 2020. 馬思唯 Masiwei, Knowknow. “口罩” (Kouzhao, Mask).

20 February 2020.XZT, 直火幫 Zhi Huobang. “鏡子” (Jingzi, Mirror).

20 February 2020. Soulhan. "哥夢” (Emeng, Nightmare).

26 February 2020. JD. "Should I Say I Love You."

\section{References}

AMAR, Nathanel. 2018. "Do you Freestyle? The Roots of Censorship in Chinese Hip-hop." China Perspectives 1-2(142-3): 107-13.

ARSÈNE, Séverine. 2011. Internet et politique en Chine (Internet and Politics in China). Paris: Karthala.

CARLET, Yasmine, and Jean-Marie SECA. 2005. "Vingt ans de Live Aid : comment le charity rock a-t-il transformé l'engagement politique en musique populaire ?" (Twenty years of Live Aid: how did charity rock transform political engagement into popular music?). Les cahiers de psychologie politique 7.

CHEN, Thomas. 2015. "Remplir les blancs. 'Publicité' et censure dans La Capitale déchue de Jia Pingwa" (Blanks to be Filled: Public-Making and the Censorship of Jia Pingwa's Decadent Capital). Perspectives chinoises 1(130): 15-23.

CHEN, Zifeng, and Clyde YichengWANG. 2020. "The Discipline of Happiness: The Foucauldian Use of the 'Positive Energy' Discourse in China's Ideological Works." Journal of Current Chinese Affairs 48(2): 201-25.
FUNG, Anthony Y.H. 2008. "Western Style, Chinese Pop: Jay Chou's Rap and Hip-Hop in China." Asian Music 39(1): 69-80.

GOW, Joe. 1994. "Political themes in popular music videos: MTV's 'Top 200, Ever'." Popular Music and Society 18(4): 77-89.

GU, Yu 穀羽, and ZHOU Yemei 周葉美. 2019. “從'地下到'大衆' 嘻哈 音樂人的迎合式文化應變策略研究" (Cong "dixia" dao "dazhong": Xiha yinyue ren de yinghe shi wenhua yingbian celue yanjiu, From "underground" to "popular": a study on the cultural contingence of hip-hop musicians). 東南傳播 (Dongnan Chuanbo, South-east Communication) 7:94-7.

VELASCO-PUFLEAU, Luis. 2013. "Chansons humanitaires, dépolitisation des conflits et moralisation des relations internationales à la fin de la Guerre froide" (Humanitarian songs, depoliticisation of conflicts and moralisation of international relations at the end of the Cold War). Relations internationales 156(4): 109-23.

ZOU, Sheng. 2019. "When Nationalism Meets Hip-Hop: Aestheticized Politics of Ideotainment in China." Communication and critical/cultural studies 16(3): 178-95. 